\title{
Provision for the poor and the mission of the church: Ancient appeals and contemporary viability
}

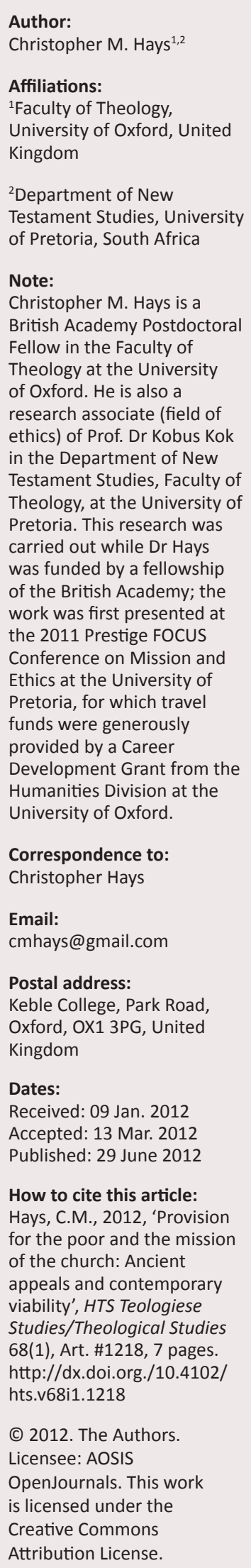

Author:

Affiliations:

${ }^{1}$ Faculty of Theology, University of Oxford, United

Kingdom

Note:

Christopher M. Hays is a Fellow in the Faculty of Theology at the University of Oxford. He is also a research associate (field of Testament Studies, Faculty of Theology, at the University of carried out while Dr Hays was funded by a fellowship of the British Academy; the work was first presented at the 2011 Prestige FOCUS

Conference on Mission and funds were generously provided by a Career Development Grant from the Humanities Division at the sity of Oxford.

Correspondence to:

Email:

Postal address:

Oxford, OX1 3PG, United

Received: 09 Jan. 2012

Accepted: 13 Mar. 2012

ublished: 29 June 201

Hays, C.M 2012 'Provisio

for the poor and the mission

of the church: Ancient

appeals and contemporary

viability', HTS Teologiese

http://dx.doi.org./10.4102/

Licensee: AOSIS

OpenJournals. This work

Creative Commons
Composed for the 2011 Prestige FOCUS Conference on Mission and Ethics at the University of Pretoria, this essay addressed the interrelationship between the New Testament conception of mission and one of the most significant moral topics in Scripture: the provision for the needy. In keeping with the investigative focus of the conference, the article began with an exegetical analysis of Matthew, Luke, the Pauline Epistles, James, and 1 John, demonstrating that generosity to the poor is an integral feature of these authors' understanding of mission. The second half of the article investigated the rhetorical and theological strategies utilised by the aforementioned New Testament authors in motivating their readership to charitable action. Without aiming to be exhaustive, the article identified ten different strategies utilised by the New Testament texts in question: the authority of Jesus, the imitation of Christ, the theology of the cross, the imitation of the saints, equality, eschatological punishment, eschatological reward, earthly blessings, observing the Law, and love. The author not only described the ways in which these appeals functioned, but evaluated to what degrees and in which 21st century global Christian contexts these various appeals might be effective in motivating contemporary expressions of provision for the needy.

\section{Introduction}

'Lord, when was it that we saw you hungry or thirsty or a stranger or naked or sick or in prison, and did not take care of you?' (Mt 25:44).

This essay will examine the relationship between mission and ethics in the New Testament, with specific focus on the subject of provision for the needy. Writing on this subject is the exegetical equivalent of picking low-hanging fruit, since the themes of riches and poverty are liberally splashed across the New Testament. The trickier task is translating these exegetical findings into compelling paraenesis, an endeavour at which the Church does not seem to have proved as successful as one might hope (cf. Rowland 1995:221).

As such, this essay will investigate not only the dynamic relationship between wealth ethics and mission in the New Testament, but the way in which New Testament wealth ethics can stimulate today's Church in her mission. I will proceed in two stages. The first and easier step will be to show how many New Testament authors consider care for the poor to be a fundamental component of Christian mission. The second stage will inquire into the various strategies utilised by New Testament authors in order to stimulate their audiences to care for the poor. But because I would like to avoid reducing this paper to a descriptive exposition, I will also ask whether these paraenetic strategies might successfully stimulate 21st century churches to social action on behalf of the marginalised.

\section{Provision for the poor and the mission of the New Testament}

I begin then with the relatively simple task of showing that most New Testament authors understood care for the needy to be basic to the mission of the disciples of Jesus.

This is of course a point writ large in the Gospel of Luke, though as a Luke scholar I'll try to restrain myself from all but the most basic of comments. The intimate connection between the gospel and the poor is veritably trumpeted in the Nazareth Synagogue sermon (Lk 4:16-20), widely recognised to be one of the programmatic texts of Luke's Gospel. When Jesus arrives proclaiming his Good News to the poor, Luke shows his Messiah to be one who brings about both spiritual and social liberation, a point made all the more clear as the gospel proceeds, blessing the poor, warning the rich (Lk 6:20-26), and exhorting the disciples to prepare for the Kingdom by serving those to whom Jesus proclaimed it (Lk 14:7-24). So also, in Luke's second book, the Acts 
of the Apostles, the mission of the Church entails both the proclamation of Jesus' teaching and provision for the poor. The Jerusalem Community, portrayed as the early and faithful instantiation of Jesus' teaching (see Hays 2010:209-211, 225), practices a fellowship that is comprised not only of collective worship, learning, and prayer, but also of table-fellowship and redistribution of goods from the 'haves' to the 'havenots' (Ac 2:42-47; 4:32-35).

But it is not just Luke, that favoured Evangelist of liberation theologians (cf. Hays 2010:20-23) and idealistic college students, that interrelates wealth ethics and the Kingdom of God. Matthew bangs that same drum. His famed account of the Judgement of the Sheep and the Goats (Mt 25:31-36) is a terrifyingly 'works-based' apocalypse. As the Son of Man presides terribly and gloriously in the heavenly throneroom, separating the righteous from the wicked, ushering the former into eternal beatitude while he casts the latter into perdition, it is not on the basis of accurate confession, a faith-filled heart, or an experience of existential encounter that people are judged. No, fidelity to Jesus is there evaluated on the basis of one's service of the impoverished, invalid, and incarcerated. While one might justly aver that Matthew could not envision salvation apart from faithful confession of Jesus, baptism and confession are so profoundly connected to care for the indigent that Matthew foretells damnation for neglect of the poor, ${ }^{1}$ regardless of whether or not one claims Jesus as Lord (Mt 25:44).

For a long time Paul was a marginal figure in conversations on poverty: the man seemed too occupied with faith and sex and circumcision to care much about the hungry. But recently this construal of Paul has come under fire, as Bruce Longenecker's (2010) excellent new monograph Remember the Poor has argued that the commitment to the poor was integral to Paul's message. The Pauline epistles (Gl 2:10; 6:9-10; 1 Th 5:14; Rm 12:13; 1 Cor 13:3; 2 Cor 8-9) and the witnesses to Paul given by the disputed Pauline epistles (Eph 4:28; Tt 3:14; $1 \mathrm{Tm} 6 ; 7,18$ ), the Acts of the Apostles (Ac 20:33-35), and the Acts of Paul and Thecla $(\$ \S 23,41)$ reveal that care for the poor was a hallmark of the Pauline communities (Longenecker 2010:135-156). According to Longenecker, charity was an alternative expression of Jewish-Christian piety over against circumcision, a compelling missiological strategy in less-charitable pagan environs, and indeed, an expression of cruciform, self-divesting love of neighbour (Longenecker 2010:183-219).

Moving into the Catholic Epistles, we come first to James. Famed for the assertion that faith and works are inseparable in the economy of salvation (though this idea is hardly news to anyone who has read the Synoptics), we sometimes forget that when James describes the 'works' apart from which faith is 'dead' (Ja 2:17), he refers to feeding and clothing the poor and the naked (Ja 2:15-16; see further Kammell 2009:157-175).

The same argument is made by 1 John. As anyone who reads this slightly repetitive epistle knows, John boils all

1.On the scope of the "poor' in question, see Rowland (1994:514-517). of Christianity down to the confession of Christ and the commandment to love one's neighbour (1 Jn 3:23). John also avers that the 'love of God' consists of obeying the commandments (1 Jn 5:3), which means that the double lovecommand ('love the Lord your God with all your heart ... and love your neighbour as yourself') is certainly rolling around in John's head, and that he understands that double love-command as the distillation of 'the commandments' (cf. Brown 1982:470-471; Bultmann 1973:58-59). But, if I can be permitted to invoke the early nineties dance hit, what is love? According to John, love consists of laying down our lives for one another (1 Jn 3:16); indeed, John boldly argues that God's love cannot possibly abide in us if we fail to help those in need (1 Jn 3:17): 'but if anyone has the world's goods and sees his brother in need, yet closes his heart against him, how does God's love abide in him?'

So, for John, James, Paul, Matthew, Luke, and, indeed, Jesus himself (see below; cf. Dunn 2003:519-526; Hengel 1974:23-30), following Christ cannot be separated from caring for the poor. ${ }^{2}$ Naturally, I cannot dispute that there are some New Testament texts that evince very little interest in the subject of wealth ethics; if one were to privilege John's Gospel above the rest of the canon, for example, one might not feel compelled to recognise the integral role of loving the needy in the Christian mission. ${ }^{3}$ But for those who see value in the canonical shape of the New Testament, who want to allow the voices of the New Testament texts collectively to shape our thought, to define in fully-orbed terms what is our mission as the people of God, there can be no doubt that aiding the vulnerable ought to comprise a central element of our activity.

\section{Motivating care for the poor: New Testament strategies and 21st century feasibility}

No fancy footwork or rhetorical wizardry is required to make the case that the proclamation of the Kingdom of God and the work of the Church entail serious commitment to the poor. But considering the challenge of moving Christians to such generosity, what can be said about the way the New Testament authors motivated their audiences to such action in the first century? ${ }^{4}$ And, lest I be accused of dragging into my ivory tower a topic that belongs in the pulpits and on the streets, to what degree can the strategies of the New Testament authors be of assistance to the rhetoric and mission of the Church today?

\section{The authority of Jesus}

At the risk of stating the obvious, the most important strategy of the New Testament authors attempting to

2.One might well mention Mark's Gospel, which certainly exhibits concern for issues of wealth ethics (see e.g., Mk 4:18-19; 10:17-31; 12:41-44), but the link between mission and provision for the poor is less prominent in Mark, so I have left it to the side for the time being; see further Barton (2009:45-49).

3.One must widen the angle of the interpretive lens to include 'the marginalized' before one can begin to develop a Johannine theology of the needy; so Motyer (1995:70-89); Karris (1990). 4. One could and should of course investigate how this subject was also approached
by Old Testament texts or in Christian history, but for the purposes of this essay, the by Old Testament texts or in Christian history, but for the purposes of this essay, the
New Testament provides ample material. I have engaged in a similar study of the early Church Fathers in Hays (2009a:260-280). 
motivate generosity was: citing Jesus. Jesus made all sorts of very bald statements about charity. Without qualification, he commanded 'Sell your possessions and give alms' (Lk 12:33), and 'Give to everyone who begs from you and do not refuse anyone who wants to borrow from you.' (Mt 5:42; so also Lk 6:30)..$^{5}$ Should not that be sufficient motivation to charity for those who consider Jesus to be their Lord?

Now, I am from a country where one often sees bumper stickers saying things like 'God said it, I believe it, that settles it', according to which one might think that conservative American Christians would be leading donors to the poor, rather than outspoken opponents of welfare. But I suppose that it would be easier for us to take Jesus seriously if the things he said didn't sound so insane. ('Do you really mean that you should give to every dope-fiend with a needle in his arm?') Texts like Luke 6:30 or Matthew 5:42 pushed some of the early Church fathers to careful reflection on the person to whom one should give, in light of one's limited resources; that sort of moral reflection implies (what is obvious to biblical scholars) that there is more involved in interpreting Scripture than simply reading the words off the page and applying them to one's life, and a possibility which is not countenanced by reductionist biblicism. Instead, Western pastors (and many scholars) who exposit these texts are more inclined to argue that Jesus did not really mean what he said, trying to stop the Gospel texts in their tracks rather than steer generosity in the best direction. As a consequence, a 2011 poll revealed that US evangelicals were more likely than non-evangelicals (Christian or not) to favour cuts to federal spending on aid to the poor (foreign and domestic), unemployment and health-care, and less likely than nonevangelicals to favour an increase in federal spending on aid to the world's poor, health care, and unemployment (Grant 2011). This could be viewed as a disheartening ideology from the most 'biblicist' demographic in the US, though it may have as much to do with the political ideologies operative amongst evangelicals as it does with their reading of Scripture. ${ }^{7}$ Irrespective of whatever accounts for these views, I remain inclined to say that there are enough people who are interested in Jesus' own opinion that just letting him speak about giving to the poor might do us a lot of good.

\section{Imitatio Christi et Theologia Crucis}

Moving a bit further in the theological direction, what about the notion of the imitatio Christi? In 2 Corinthians 8:8-9 Paul appeals to Jesus' voluntary divestiture of his own heavenly riches as a model for the giving of the Corinthians:

For you know the grace of our Lord Jesus Christ, that though he was rich, yet for your sake he became poor, so that you by his poverty might become rich. (2 Cor 8:8-9)

5.See further the Matthew 19:21; Mark 10:21; Luke 18:22; Acts 20:35. Of course, Paul (GI 2:10; 6:10; Rm 12:13), 'Deutero-Paul' (Eph 4:28; Tt 3:14), and the author to Hebrews (Heb 13:16) say similar things.

6.Did. 1:6; Clement of Alexandria, Fragments from the Hypotyposes 2:3; Strom. 7:12; cf. Sir 12:4-7.

7.By contrast, the 2010 Pew Forum 'Global Survey of Evangelical Protestant Leaders' indicated that $97 \%$ of evangelical leaders thought that working to help the poor and indical needy was either he sa surve showed that $81 \%$ of those surveyed thought that the government had a 'responsibility to take care of very poor people', though amongst US leaders, that number was only $56 \%$, with a startlingly $40 \%$ saying that they mostly or strongly disagree (Lugo 2011:83).
By these means he attempts to stimulate the Corinthians to give to the Collection. 1 John makes a very similar argument:

We know love by this, that he laid down his life for us - and we ought to lay down our lives for one another. How does God's love abide in anyone who has the world's goods and sees a brother or sister in need and yet refuses help? (1 Jn 3:16-17)

Defining Jesus' love in terms of his self-sacrifice, and then calling his readers to lay down their lives for one another, John goes on to call for such self-sacrificial love in giving to the needy. Might the imitation of Christ, or the theology of the cross, stimulate contemporary Christians to self-sacrificial charity?

In my experience as a US-born Christian, I have not observed the theologia crucis getting much airtime in popular discourse. My home country is big on success, comfort, progress, and the inviolability of property rights, and as such few are likely to warm quickly to the New Testament call to suffering, divestiture, and indeed, challenge to the propriety of preserving one's property for oneself. The theology of the cross that rightly receives plenty of attention in the US is part of soteriological discourse, the idea being that Christ suffered so that we do not have to do so in hell. All that is quite true, but it does not mean that Christ suffers so that we do not have to suffer or sacrifice at all; such a reading leaves to the side Jesus' many clear statements that being his disciple requires us to pick up our cross and follow him (Mt 10:38; 16:24; Mk 8:34; Lk 9:23; 14:27).

The context in which the theologia crucis has been applied to wealth ethics is in liberation theology (albeit, even there, only to a limited degree); the liberationist emphasis on solidarity fits neatly with the theology of the cross. As Javier Jiménez Limón (1993) articulated it:

liberating theology of the cross is defined materially by Christian solidarity. This solidarity is historical and practical, emotional and effective, partial and universal, transforming and kenotic, made possible by the liberating and redeeming event of Jesus Christ, which is its standard. (p. 706) ${ }^{8}$

Unfortunately, linkages made between solidarity and communism yoked the Latino liberationist theology of the cross to a sinking politico-economic ship, allying it to an ideology which most North Americans would not touch with a ten-foot pole. Still, liberationist insights can be reappropriated, even for a US context, and if we replace the word 'solidarity' with 'unity', nobody would be the wiser. Naturally, a contemporary effort at kenotic and transformative Christian ethics, a liberationist theologia crucis, could combine sacrificial expenditure with a more economically promising charitable model. In this sense, Christians can remain in lucrative employment but practice the theology of the cross in denying themselves the trappings of success, the fancy house, car, clothes, and vacations their affluence affords them, in order to live simply AND support the needy. And of course, when I talk about supporting the needy, I do not refer only (or even primarily) to emergency aid and welfare.

8.This is actually a secondary feature of the liberation theology of the cross; more commonly, liberation theology will characterise suffering people as 'crucified' and in need of 'resurrection'; see for example Ellacuría (1993:580-603); Sobrino (2001:43-49). 
One might well argue that the best way to support the poor is through funding micro-loan programmes, education, or indeed opening ethical corporations in poor communities. ${ }^{9}$

\section{Imitatio Sanctorum}

If we are going to talk about the imitation of Christ, might we not also consider encouraging people to imitate the saints? After all, Paul uses the example of the Macedonians (giving beyond their means; 2 Cor 8:3) to shame the Corinthians into supporting the Collection, and Jesus extolled the poor widow who cast her last two lepta into the Temple treasury (Mk 12:41-44; Lk 21:1-4), inviting his disciples to think of generosity in terms of how little is kept, not how much is given. Luke makes a veritable narrative strategy of adducing ethical exemplars of generosity to be imitated by his readers, ${ }^{10}$ lauding the examples of Zacchaeus (Lk 19:1-10), the Jerusalem Community (Ac 2:43-46; 4:32-35), Barnabas (Ac 4:36-37), Tabitha (Ac 9:36), Cornelius (Ac 10:2), the Antiochian Church (Ac 11:27-30), and of course Paul (Ac 20:33-35; cf. 24:17). Can we not adduce similar paradigmatic figures ${ }^{11}$ to stimulate generosity today?

I would wager as much, but this has to be done with a degree of prudence when we are addressing typical laity. People are fond of holding up Mother Theresa as a source of Christian inspiration. Pragmatically speaking, however, the trouble with Mother Theresa herself is that she was a person of such proverbial piety that imitating her seems essentially impossible. Likewise, pointing to the generosity of people like Bill and Melinda Gates ${ }^{12}$ can be counterproductive, since the impact of the ultra-rich undermines the sense that John Q. Public can also make an impact. Perhaps, however, we can take a page from the New Testament playbook by noting the way that many of the models for imitation are average people (Tabitha, the widow, the Macedonians), even people with questionable pedigrees (Zacchaeus, Cornelius). These are 'realistic exemplars', people we can approximate and nonetheless be inspired by. That is why a figure like Shane Claiborne (see e.g., Claiborne 2006), the spokesperson for the New Monastic movement in the US, is so effective. With his down-home humour, Tennessee accent, and baggy clothes, Shane is familiar enough for an American student to identify with, even though his life of sacrificial generosity and simplicity have made him something of a sensation amongst idealistic Christian youth. One simply has to find figures that walk the line between being accessible and inspiring.

\section{Equality}

Beyond lauding the figures of Christ (the rich who became poor) and the Macedonians (the poor who became poorer) as exemplars that the Corinthians should imitate, Paul makes

9.One might well point out that these industries are often for-profit, but the risks might be higher or the returns lower; in these cases, the theology of the cross might stimulate the investor to engage in this less-lucrative investment.

10. Hays (2010:138-139 et passim); Kurz (1990:171-189); Syreeni (1991:36-57).

11.On paradigmatic figures (or Identifikationsfiguren) and narrative-critical theory, see Powell (1993:56-57); Petzke (1990:217); Gradl (2005:180, 201-202), et passim.

12. Not to number the Gates amongst the saints; I cannot speak to their religious affiliation. a third, more philosophical appeal in 2 Corinthians, he calls for equality:

Our desire is not that others might be relieved while you are

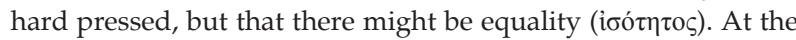
present time your plenty will supply what they need, so that in turn their plenty will supply what you need. Then there will be equality. (2 Cor 8:13-14, NIV)

Naturally, Paul does not possess a full-blown philosophical conception of equality; he is primarily concerned that everyone's needs are provisioned, as is evidenced by his citation of Exodus 16:18 in 2 Corinthians 8:15. When it comes to answering more-precise philosophical questions (equality of welfare? equality of resources?), Paul leaves us largely to our own devices.

The notion of equality was put to good use in patristic argumentation (see e.g. Holman 2011:115-116); might Paul's concept of equality prove helpful to us in contemporary discourse? In the US, I do not know how optimistic one should be. Naturally, in principle the US believes in equality (it is one of the great buzzwords of the modern and postmodern ages), but not in Paul's sense. Drawing on Locke's 'life, health, liberty, and possessions', ${ }^{13}$ American ideology is expressed seminally in the Declaration of Independence's proclamation:

We hold these truths to be self-evident, that all men are created equal, that they are endowed by their Creator with certain inalienable rights, that among these are life, liberty, and the pursuit of happiness. (Second Continental Congress 1776)

In other words, what we have in America is a concept of moral or ontological equality and equality of opportunity; none of that entails an obligation to see people's subsistence needs provisioned. So Paul's argument from equality will not immediately grip the American Christian; we are skittish of anything that hints of socialism (all the while not recognising that we have socialised primary and secondary education, fire and police departments, libraries, and parks).

Still, Paul's commitment to equal provision of at least people's basic needs would indeed be easily received in the United Kingdom and most of Western Europe, where the developed welfare system not only does provide for those needs, but in broad strokes has the approval of the populace (even if everyone loves to hate the mechanisms of welfare systems, and not without reason). Indeed, the general acceptability of this idea seems reflected in the 25th Article of the United Nation's Universal Declaration of Human Rights:

Everyone has the right to a standard of living adequate for the health and well-being of himself and of his family, including food, clothing, housing and medical care and necessary social services, and the right to security in the event of unemployment, sickness, disability, widowhood, old age or other lack of livelihood in circumstances beyond his control. (Commission on Human Rights 1948:25)

The Catholic Church echoed this commitment in the 1999 statement of the Pontifical Council for the Family (PCF),

13.John Locke, Second Treatise on Civil Government chapter 2, article 6, cited according to the edition of Gough (1948:5). 
entitled The Family and Human Rights. Commenting on the Universal Declaration of Human Rights, the PCF says:

Solidarity urges us to seek relations that tend toward equality on the local, national and international level ... Solidarity requires the international community to continue working to achieve global strategies that lead to combating disease and hunger and to promoting authentic human development. The normative dimension of solidarity requires us to make an effort to set up relations with the developing countries that aim at equality. In this process, however, those who enjoy the privileges of overabundance have a corresponding obligation: namely, to give generously so as to put the less fortunate in a position to achieve standards of life by themselves which are in accordance with human dignity. (§§ 55-56, [author's own emphasis])

So, though it might take some convincing to get American evangelicals to agree with Paul's account of equality, the Catholic Church and most of Europe have already embraced and excelled Paul in the robust social account of equality affirmed in the aforementioned documents.

\section{Eschatological judgement}

Of course, the New Testament is not typically as concerned about philosophical plausibility as I have been. While making virtue palatable is all well and good, the New Testament authors like to drop the hammer as well: either take care of the poor, Matthew says, or you'll go to hell (Mt 25:31-46). James adopts a similar tactic when tearing into the negligent and exploitative rich in his community: the rust on your unused (hoarded) gold will bear witness against you in the final judgement, he says (Ja 5:1-6). Let's not even get started on Luke $(3: 7-11 ; 6: 24 ; 12: 42-48 ; 16: 19-25)$. Fear of damnation is a powerful motivator.

Still, I am not sure how much traction this idea will get today. Perhaps in traditional Catholic circles in, for example Latin America, this would play well. But in countries like Germany and other Western European nations, it seems that relatively few Christians actually believe in the existence of hell (or at least that anybody will go there), in which case the threat of eternal torment might fall flat. Even in the US, where most Christians do believe that there will be a lot of people in hell, we are not particularly worried about judgement, because our exaggerated sola fideism has effectively made ethics, not just logically subsequent to soteriology, but irrelevant to it. If, however, churches that do believe in hell recover a more biblically robust understanding of the integral relationship between faith and works, love of God and love of neighbour, then perhaps this sort of discourse could be revived in those contexts.

\section{Eschatological reward}

What about the flip-side of the eschatological coin? After all, Jesus says that by giving alms we store up treasures in heaven (Mt 6:19-21; Lk 12:33-34). Luke's banquet teachings say that those who feed the poor to whom Jesus came to preach the gospel will find themselves repaid at the resurrection of the righteous (Lk 14:7-14). 1 Timothy (6:17-19) says:
Those who in the present age are rich ... are to do good, to be rich in good works, generous, and ready to share, thus storing up for themselves the treasure of a good foundation for the future, so that they may take hold of the life that really is life.

The list goes on (cf. Lk 6:38; 12:13-21, 42-48; 16:9; Gl 6:9-10).

Admittedly, there is a bit of ambiguity in what the New Testament actually claims will be the reward of this charity. I generally prefer to interpret this simply as the inverse correlate of what we discussed in the last section: if neglecting the poor leads to damnation, care for the poor leads to beatitude. That is certainly how Matthew 25 sees it, and 1 Timothy 6:17-19 indicates that the reward is eternal life itself.

Still, the dominical logia could well be taken to indicate that one will actually accumulate greater 'reward' in heaven (whatever that might mean, though some idea of increased beatitude or celestial status would be plausible in terms of the history of ideas); this does indeed fit with much of what we know from Jewish ideology. ${ }^{14}$ US evangelicals have combined this imagery with Revelation 2:10, 3:11, (the crown of life) and Revelation 4:4, 10 (24 elders casting their crowns before the Lamb), expecting that the righteous will receive more or bigger crowns in accordance with their deeds on this earth, an idea which goes well beyond what the Apocalypse implies. Still, the notion of receiving some sort of celestial recompense does seem to have traction in the Scripture and Christian tradition, even though I do not imagine that many Northern Europeans will find this particular type of selfinterested appeal to be terribly palatable.

\section{Present blessings}

Nevertheless, if people are underwhelmed by the prospect of eschatological recompense, they have proven quite eager to open their wallets when promised temporal rewards. Prosperity theology has made shocking inroads in the US, Europe, South America, Africa, and the Pacific Rim. It does have some clear grounding in the Old Testament (where it is part of a nationalist discourse in which divine blessing identifies Israel as the people of the one true God). And there is even a hint of support for it in the New Testament. In 2 Corinthians 6:6-13 Paul promises that, if the Corinthians 'sow' generously into the Collection, God will increase their 'seed' and 'enrich them in every way'. Now, the attentive reader will note that Paul promises that God will increase their seed for sowing, and enrich them in every way in order to be generous in every way, not in order to provide them greater mortal pleasures. But the fact of the matter is that an argument, however selective, can be made and is being made that giving will make you richer.

Frankly, this strategy is effective, at least at the beginning, at getting people to give away lots of money. The problem is that much of the money given ('sown') goes into the pockets of prosperity preachers, and less gets into the hands, mouths,

14.See for example, t. Pe'ah 1:2; 4:18; b. Ros. Has. 4a; B. Bat. 10a-11a; Ex. Rab. $31: 14$ Midr. Pss. 118:18; see further Hays (2010:44-45). 
and bellies of the poor. And when the prosperity theology is shown not to work, people will not only stop giving, but indeed, often will stop believing in Christianity more generally. So you will understand that I would not espouse the use of this 'New Testament' strategy to encourage generosity.

\section{Obeying the Law}

One of the New Testament's favoured strategies in stimulating charity, surprising though it be to those of us of Protestant and/or Lutheran extraction, is appeal to the Law. In the Parable of Dives and Lazarus (Lk 16:14-31), Luke avers that adherence to the 'Moses and the Prophets' would save Dives' brothers from perdition, and in the Lukan context Moses and the Prophets point to feeding the hungry, clothing the naked, and caring for the poor to whom Jesus (the Messiah prophesied by the Law) preached the message of repentance. ${ }^{15}$ So also, James and John, following Jesus' lead in interpreting the command to love one's neighbour as oneself as the distillation of the Law, claim that love entails caring for the needs of the impoverished (Ja 2:8-17; 1 Jn 2:3, $7 ; 3: 22-24)$.

Many contemporary churches, however, are highly supersessionist, believing somehow that Jesus 'fulfilled' the Law in a way that made its tenets irrelevant. We need a more nuanced account of how the Law is handled in the New Testament, one which appreciates the revelatory character of the Law and appropriates it for ethics. If the Law is indeed part of God's self-revelation, in some way or another, we surely need to say that in whatever way it does speak for God, Jesus' 'fulfilment' of the Law entails a lot more than setting it aside. Even if Matthew and Paul want to emphasise the contrast between Jesus and the Law (or more pointedly, the way Jesus interprets the content and function of the Law as opposed to the way that Pharisaic Judaism did so), surely the canonical voice that includes James, John, and Luke, should restrain us from any wholesale discarding of the Law, noting the deep and fundamental coherence between the values of the Law and Jesus (see e.g. Bockmuehl 2000:1-83; Hays 2010:123-125). Refusal to capitulate to supersessionism will enable biblical scholars to draw on an enormous well of biblical texts (and theology) in our ethics, opening to us the resources of the Sabbath and Jubilee years, a theology of creation, principles of lending and giving, not to mention unshackling the prophetic imperatives to justice and mercy. ${ }^{16}$

\section{Love}

This talk of 'distillation of the Law' brings us back into territory that is much more comfortable for New Testament scholars influenced by liberal theology. Or at least the idea of construing the Law in terms of loving one's neighbour as oneself is attractive; in practice, however, this theological move leaves the Christian in a vulnerable position, as

15. Hays (2010:156-158); cf. the use of Isaiah 58:6-7 in Luke 3:11; 4:18-20; Leviticus 19:18 in Luke 10:25-26; Isaiah 61:1-2 in Luke 4:16-20. Note further the way that Luke sees the fellowship of the Jerusalem Community as a fulfilment of the Law, alluding to Deuteronomy 15:4 in Acts 4:34.

16.Such an approach is exemplified in Wright (1990). it entails an overwhelming, indeed, impossible level of obligation. When Matthew tells the story of the rich young ruler, he inserts the love command into the Decalogue citation he adopts from his Markan source (Mt 19:19); as a result, he makes the divestiture and charity prescribed to the rich ruler a matter of loving his neighbour. Luke's Good Samaritan parable makes the interpretive step of defining the neighbour whom one is to love as oneself in the broadest terms possible: you are to love as yourself anyone to whom you can become a neighbour (Lk 10:25-37; cf. Hays 2010:119; Reicke 1970:107). ${ }^{17} \mathrm{Now}$, to anyone paying attention, this idea should be terrifying: if we put two and two together, reading the Synoptic comments on love of neighbour canonically, it would imply that we who hope to enter the Kingdom of God are required to love as ourselves anyone whom we can possibly find, especially the poor, and to express that love by prioritising the needs of the poor just as highly as our own. The profundity of that idea alone might be seen as a good reason not to read the New Testament texts canonically. But even if we were to refuse to draw these two texts together in a Synoptic duet, we could not escape this inference, because 1 John makes this connection explicit (so also Brown 1982:473-475). 'But if anyone has the world's goods and sees his brother in need, yet closes his heart against him, how does God's love abide in him?' (1 Jn 3:17).

Of all the New Testament strategies to motivating care for the poor, surely this one is the most devastating, the most gutting, and the most ludicrously far-reaching. And yet this is also the strategy that I would imagine would have the most universal and compelling appeal, for all breeds of Christianity, from the fundamentalist to the ultra-liberal, would agree with the centrality of the double love-command. Moreover, the logic of 1 John is both elegantly simple and indisputable. This is an inexhaustible imperative, it yawns wide and demands that our entirety be given over to the love of God and neighbour; but this is precisely what Jesus said from the beginning, as he demanded that his followers renounce all their possessions ${ }^{18}$ and hate their families (Mt 10:37; Lk 14:26) ${ }^{19}$ and sacrifice even their own lives for him. ${ }^{20}$ Nothing less than everything will satisfy our God, which leaves us with nothing to hope in or cling to except the faith that the one to whom we devote all is good and pro nobis. And so, as people of faith who seek to be drawn deeper into the love of God and neighbour, as we seek to exhort ourselves and others to faithful discipleship, we must begin with confession and prayer, admitting that we do not love our neighbours as ourselves, and beseeching God to awaken us to greater love.

\section{Conclusion}

This essay began by articulating the integral role of wealth ethics in the mission of the Church; frankly, it was an easy

17.After writing this section, I discovered that John Wesley also combined the Love Command and the Parable of the Good Samaritan in his exhortations to charity (Withrow 2007:32-33).

18.Luke 14:33; Matthew 19:21; Mark 10:21; Luke 18:22.

19.On the connections between hating family and renouncing wealth, see further Hays (2009b:47-68).

20.Matthew 16:24-25; Mark 8:34-35; Luke 9:23-24; Matthew 10:38-39; Luke 14:27; 17:33; John 12:25. 
argument to make, since Matthew, Luke, James, 1 John, and even Paul characterise provision for the poor as an inseparable element of Christian discipleship. I then queried the New Testament authors to find out how they went about attempting to motivate their audiences to such generosity. Even a quick survey uncovered a variety of appeals to the authority of Jesus' teaching, the examples of the saints, and the imitation of Christ's self-divestiture and suffering. The biblical authors threatened their readers with eschatological judgement and promised reward in this life and the next. They also appealed to the notion of equality, the propositions of the Law, and indeed, the one concept that they thought summed up the entirety of the Law: love.

Finally, I argued that the New Testament strategies would not all be equally effective in motivating Christian ethics in various ecclesial contexts around the globe; the theological and socio-political commitments of diverse Christian communities are such that an appeal that might prove compelling in one part of the world would fall flat elsewhere. Nonetheless, if I were pressed to suggest a pair of ideas most likely to have a universal appeal, I would have to point to the way that the apostles invoked the authority of Jesus and the demands of love. The fundamental authority of the Lordship of Christ and the undeniable logic of love seem most likely to challenge and motivate Christians of all stripes.

\section{Acknowledgements}

\section{Competing interests}

The author declares that he has no financial or personal relationship(s) which may have inappropriately influenced him in writing this article.

\section{References}

Barton, S., 2009, 'Money matters: Economic relations and the transformation of value in early Christianity', in B.W. Longenecker \& K. Liebengood (eds.), Engaging economics: New Testament scenarios and early Christian reception, pp. 37-59, Eerdmans, Grand Rapids, MI.

Bockmuehl, M., 2000, Jewish law in Gentile Church: Halakhah and the beginning of Christian public ethics, Baker Academic, Grand Rapids, MI.

Brown, R.E., 1982, The epistles of John: Translated with introduction, notes, and commentary, Geoffrey Chapman, London. (Anchor Bible).

Bultmann, R., 1973, The Johannine epistles: A commentary on the Johannine epistles, Fortress, Philadelphia, PA. (Hermeneia).

Claiborne, S., 2006, The irresistible revolution: Living as an ordinary radical, Zondervan, Grand Rapids, MI.

Commission on Human Rights, 1948, Universal Declaration of Human Rights, viewed 11 April 2012, from http://www.un.org/en/documents/udhr/

Dunn, J.D.G., 2003, Jesus remembered, vol. 1, Eerdmans, Grand Rapids, MI. (Christianity in the Making)

Ellacuría, I., 1993, 'The crucified people', in I. Ellacuría \& J. Sobrino (eds.), Mysterium liberationis: Fundamental concepts of liberation theology, pp. 580-603, Orbis, Maryknoll, NY.

Gough, J.W., 1948, The second treatise of civil government, and a letter concerning toleration, Blackwell, Oxford.
Gradl, H-G., 2005, Zwischen Arm und Reich: Das lukanische Doppelwerk in leserorientierter und textpragmatischer Perspektive, Echter, Würzburg.

Grant, T., 2011, 'Polling evangelicals: Cut aid to world's poor, unemployed', Christianity Today, viewed 25 Februrary 2012, from http://www.christianitytoday.com/ ct/2011/februaryweb only/cutaidtoworldspoor.html

Hays, C.M., 2009a, 'By almsgiving and faith sins are purged? A critical analysis of the theological underpinnings of second and third century Christian almsgiving', in B.W. Longenecker \& K. Liebengood (eds.), Engaging economics: New Testament scenarios and early Christian interpretation, pp. 260-280, Eerdmans, Grand Rapids, MI.

Hays, C.M., 2009b, 'Hating wealth and wives? An examination of discipleship ethics in the Third Gospel', Tyndale Bulletin 60(1), 47-68.

Hays, C.M., 2010, Luke's wealth ethics: A study in their coherence and character, Mohr Siebeck, Tübingen. (Wissenschaftliche Untersuchungen zum Neuen Testament, zweite Reihe, vol. 275)

Hengel, M., 1974, Property and riches in the early Church, Fortress, Philadelphia, PA.

Holman, S.R., 2011, 'Out of the fitting room: Rethinking patristic social texts on "the common good"', in J. Leemans, B.J. Matz \& J. Verstraeten (eds.), Reading patristic texts on social ethics: Issues and challenges for twenty-first-century Christian social thought, pp. 103-123, Catholic University of America Press, Washington, DC. (CUA studies in early Christianity).

Jiménez Limón, J., 1993, 'Suffering, death, cross, and martyrdom', in I. Ellacuría \& J. Sobrino (eds.), Mysterium liberationis: Fundamental concepts of liberation theology, pp. 702-715, Orbis, Maryknoll, NY.

Kammell, M., 2009, 'The eonomics of humility: The rich and humble in James', in B.W. Longenecker \& K. Liebengood (eds.), Engaging economics: New Testament scenarios and early Christian interpretation, pp. 157-175, Eerdmans, Grand Rapids, MI.

Karris, R.J., 1990, Jesus and the marginalized in John's Gospel, Liturgical, Collegeville, MN. (Zacchaeus Studies: New Testament).

Kurz, W.S., 1990, 'Narrative models for imitation in Luke-Acts', in D.L. Balch (ed.) Greeks, Romans, and Christians: Essays in honor of Abraham J. Malherbe, pp. 171-189, Fortress, Minneapolis, MN

Longenecker, B.W., 2010, Remember the poor: Paul, poverty, and the Greco-Roman world, Eerdmans, Grand Rapids, MI.

Lugo, L., 2011, 'Global survey of evangelical protestant leaders', Pew Forum on Religion and Public Life, Washington DC, viewed 25 February 2012, from http:// www.pewforum.org/Christian/Evangelical-Protestant-Churches/Global-Surveyexec.aspx

Motyer, S., 1995, 'Jesus and the marginalised in the Fourth Gospel', in A. Billington, T. Lane \& M. Turner (eds.), Mission and meaning: Essays presented to Peter Cotterell, pp. 70-89, Paternoster, Carlisle.

Petzke, G., 1990, Das Sondergut des Evangeliums nach Lukas, Theologischer Verlag, Zürich. (Züricher Werkkommentare zur Bibel).

Pontifical Council for the Family, 1998, The Family and Human Rights, viewed 11 April 2012, from http://www.vatican.va/roman_curia/pontifical_councils/family/ documents/rc_pc_family_doc_20001115_family-human-rights_en.html

Powell, M.A., 1993, What are they saying about narrative criticism? A new approach to the Bible, SPCK, London.

Reicke, B., 1970, 'Der barmherzige Samariter', in O. Böcher \& K. Haacker (eds.), Verborum veritas: Festschrift für Gustav Stählin zum 70. Geburtstag, pp. 103-109, Theologischer Verlag Rolf Brockaus, Wuppertal.

Rowland, C., 1994, 'Apocalyptic, the poor, and the Gospel of Matthew', Journal of Theological Studies 45(2), 504-518. http://dx.doi.org/10.1093/jts/45.2.504

Rowland, C., 1995, "'The gospel, the poor and the churches": Attitudes to poverty in the British churches and biblical exegesis', in J.W. Rogerson, M. Davies \& R. in the British churches and biblical exegesis', in J.W. Rogerson, M. Davies \& R. 213-231, Sheffield Academic Press, Sheffield. (Journal for the Study of the Old 213-231, Sheffield Academic Press, She
Testament Supplement Series, vol. 207).

Second Continental Congress, 1776, United States Declaration of Independence viewed 11 April 2012, from http://www.archives.gov/exhibits/charters/ viewed 11 April 2012,
declaration transcript.html.

Sobrino, J., 2001, Christ the liberator: A view from the victims, Orbis, Maryknoll, NY.

Syreeni, K., 1991, 'The gospel in paradigms: A study in the hermeneutical space of Luke-Acts', in P. Luomanen (ed.), Luke-Acts: Scandinavian perspectives, pp. 36-57, Vandenhoeck \& Ruprecht, Göttingen.

Withrow, L.R., 2007, 'Success and the prosperity gospel: From commodification to transformation: A Wesleyan perspective', Journal of Religious Leadership 6(2), 15-41.

Wright, C.J.H., 1990, God's people in God's land: Family, land, and property in the Old Testament, Eerdmans, Grand Rapids, MI. 